\title{
The ubiquitin hydrolase, USP22 contributes to 3'- end processing of JAK-STAT inducible genes
}

\author{
Edmond Chipumuro, Melissa A Henriksen ${ }^{*}$ \\ From Epigenetics and Chromatin: Interactions and processes \\ Boston, MA, USA. 11-13 March 2013
}

5'-capping, splicing and 3'-cleavage/polyadenylation of a nascent RNA transcript are all coupled to transcription. Transcription is regulated by the post-translational modification of histones at the chromatin template. How histone modifications affect cotranscriptional RNA processing, however, is not well understood. By studying how the chromatin template contributes to the dynamic gene expression induced downstream of the JAK-STAT signaling pathway, we have uncovered relationships between specific histone modifications and RNA processing. Here we report that $\mathrm{H} 2 \mathrm{~B}$ monoubiquitination ( $\mathrm{ubH} 2 \mathrm{~B}$ ) is required for the effective 3 '-end processing of the JAKSTAT inducible transcript, IRF1. RNAi-mediated depletion of the ubiquitin hydrolase, USP22 increases ubH2B levels and decreases transcriptional elongation at IRF1. Unexpectedly, 3'-end cleavage and polyadenylation of IRF1 is diminished, leading to a 2-to-3-fold increase in unprocessed IRF1 transcripts. The polyadenylation factor, CPSF73 is not effectively recruited and serine 2 phosphorylation (Ser2P) of the C-terminal domain of RNA polymerase II is disrupted. Two other JAK-STAT inducible transcripts are similarly affected, while two constitutively expressed transcripts are not. A working model, wherein a cycle of $\mathrm{H} 2 \mathrm{~B}$ ubiquitination/deubiquitination specifies Ser2P to regulate elongation and 3'-end processing of JAK-STAT inducible mRNAs is proposed. These results further elaborate USP22 function and its role as a putative cancer stem cell marker.

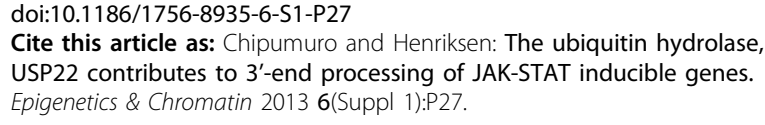

Department of Biology, University of Virginia, Charlottesville, VA, USA
Submit your next manuscript to BioMed Central and take full advantage of:

- Convenient online submission

- Thorough peer review

- No space constraints or color figure charges

- Immediate publication on acceptance

- Inclusion in PubMed, CAS, Scopus and Google Scholar

- Research which is freely available for redistribution
() Bïmed Central

\section{() Biomed Central}

